\title{
Caspase-2 deficiency prevents programmed germ cell death resulting from cytokine insufficiency but not meiotic defects caused by loss of ataxia telangiectasia-mutated (Atm) gene function
}

\author{
Y Morita ${ }^{1,2,6}$, DV Maravei ${ }^{1,6}$, L Bergeron ${ }^{3}$, S Wang $^{3}$, \\ GI Perez ${ }^{1}$, O Tsutsumi ${ }^{2}$, Y Taketani ${ }^{2}$, M Asano $^{4}$, \\ R Horai $^{4}$, SJ Korsmeyer ${ }^{5}$, Y Iwakura ${ }^{4}$, J Yuan ${ }^{3}$ and \\ JL Tilly ${ }^{\star, 1}$ \\ 1 Vincent Center for Reproductive Biology, Department of Obstetrics and \\ Gynecology, Massachusetts General Hospital/Harvard Medical School, \\ Boston, Massachusetts 02114, USA \\ 2 Department of Obstetrics and Gynecology, University of Tokyo, Faculty of \\ Medicine, Tokyo 113-8655, Japan \\ ${ }^{3}$ Department of Cell Biology, Harvard Medical School, Boston, Massachusetts \\ 02115, USA \\ ${ }^{4}$ Center for Experimental Medicine, Institute of Medical Science, University of \\ Tokyo, Tokyo 108-8639, Japan \\ ${ }^{5}$ Department of Cancer Immunology and AIDS, Dana-Farber Cancer Institute, \\ and Departments of Pathology and Medicine, Harvard Medical School, Boston, \\ Massachusetts 02115, USA \\ ${ }^{6}$ Y Morita and DV Maravei contributed equally to this study \\ * Corresponding author: JL Tilly, PhD, Massachusetts General Hospital, \\ VBK137C-GYN, 55 Fruit Street, Boston, Massachusetts 02114, USA. \\ Tel: 1-617-724-2182; Fax: 1-617-726-7548; E-mail: jtilly@partners.org
}

Received 14.11.00; revised 22.12.00; accepted 3.1.01

Edited by $\mathrm{G}$ Salvesen

\begin{abstract}
It is well established that programmed cell death claims up to two-thirds of the oocytes produced during gametogenesis in the developing fetal ovaries. However, the mechanisms underlying prenatal germ cell loss in females remain poorly understood. Herein we report that caspase-11 null female mice are born with a reduced number of oocyte-containing primordial follicles. This phenotype is likely due to failed cytokine processing known to occur in caspase-11 mutants since neonatal female mice lacking both interleukin (IL)-1 $\alpha$ and IL-1 $\beta$ also exhibit a reduced endowment of primordial follicles. In addition, germ cell death in wild-type fetal ovaries cultured ex vivo is suppressed by either cytokine, likely via ligand activation of type $1 \mathrm{IL}-1$ receptors expressed in fetal germ cells. Normal oocyte endowment can be restored in caspase-11 null female mice by simultaneous inactivation of the gene encoding the cell death executioner enzyme, caspase-2. However, caspase-2 deficiency cannot overcome gametogenic failure resulting from meiotic recombination defects in ataxia telangiectasia-mutated (Atm) null female mice. Thus, genetically distinct mechanisms exist for developmental deletion of oocytes via programmed cell
\end{abstract}

death, one of which probably functions as a meiotic quality-control checkpoint that cannot be overridden. Cell Death and Differentiation (2001) 8, 614-620.

Keywords: apoptosis; cell death; oocyte; ovary; caspase; ATM; Bax

Abbreviations: ATM; ataxia telangiectasia-mutated gene product (Atm, gene designation); ATR, ataxia telangiectasia-and RAD3related protein; IL-1, interleukin-1; LIF, leukemia inhibitory factor; SCF, stem cell factor (Steel gene product)

\section{Introduction}

One of the highest incidences of developmental programmed cell death in mammals occurs in female germ cells during gametogenesis in the fetal ovaries. ${ }^{1}$ For example, human females are born with only $1-2 \times 10^{6}$ oocytes, ${ }^{2}$ despite the fact that approximately $7 \times 10^{6}$ germ cells are generated by the twentieth week of gestation from clonal expansion of the primordial germ cell pool. ${ }^{3}$ Deletion of two-thirds or more of the developing germ cell population prior to birth is not unique to humans since similar proportions of germ cells are lost during gestational development of female rodents. ${ }^{4}$ Although the impact of oocyte apoptosis on ovarian function and lifespan is significant, prenatal germ cell death remains a poorly understood phenomenon. ${ }^{1}$ Similar to that proposed for developmental cell death in other models, ${ }^{5}$ much of the germ cell death in fetal ovaries may be driven by a competition for a limited supply of somatic cell-derived survival factors, such as stem cell factor (SCF). ${ }^{6}$ Indeed, genetic evidence exists identifying SCF-dependent signaling through its receptor, c-kit, as a critical component of gametogenesis in males and females. ${ }^{7,8}$ This work has recently been supported by studies of murine fetal ovaries maintained ex vivo demonstrating that SCF, in combination with a gp130-activating ligand (e.g., leukemia inhibitory factor or LIF), represses activation of programmed germ cell death in females. ${ }^{9}$

Another possibility is that apoptosis in fetal ovaries serves to eliminate those developing oocytes with meiotic recombination anomalies, thus serving as a quality control mechanism to ensure only the most competent oocytes are used for folliculogenesis. This hypothesis is directly supported by cytogenetic evidence from studies of oocyte attrition in fetal human ovaries, ${ }^{10,11}$ and indirectly by a series of intriguing observations from the ataxia telangiec- 
tasia-mutated (Atm) gene knockout mouse. ${ }^{12-15}$ In somatic cells it has been shown that the ATM protein, a serine/threonine kinase activated principally by DNA double-strand breaks, takes part in the DNA damage response pathway following exposure to radiation or radiomimetic drugs. ${ }^{16,17}$ Interestingly, targeted disruption of the Atm gene in mice not only leads to chromosomal instability and radiosensitivity in somatic cells, but also causes complete sterility in both males and females. ${ }^{12-14}$ The gonadal failure was identified to be a result of massive germ cell apoptosis in both sexes, occurring at or shortly after prophase I of the first meiotic division. ${ }^{15}$ Additional studies have shown that ATM localizes at sites along the synaptonemal complex where meiotic recombination occurs, ${ }^{18}$ and that ATM is required for association of a mammalian homolog of the yeast cell cycle checkpoint gene product, CHK1, with meiotic chromosomes. ${ }^{19}$ Further, ATM deficient spermatocytes accumulate abnormally high levels of ATR (ataxia telangiectasiaand RAD3-related) protein, ${ }^{20}$ a kinase that localizes along unpaired or asynapsed chromosomal axes during meiosis. ${ }^{21}$ Given these findings, along with reports of distorted telomere-nuclear matrix interactions leading to abnormal telomere clustering in $\mathrm{Atm}^{-1-}$ spermatocytes, ${ }^{22}$ germ cell loss in ATM deficient mice probably occurs as a direct result of numerous meiotic defects.

Using nine different single and double gene mutant mouse lines, herein we have identified a novel role for proinflammatory cytokines, derived from the caspase-11/ caspase-1 (interleukin-1 $\beta$-converting enzyme) protease cascade, as germ cell survival factors in vivo and ex vivo. Furthermore, we have provided evidence for the existence of at least two genetically distinct pathways responsible for prenatal oocyte death in the female. One of these pathways is induced by cytokine insufficiency and it relies on caspase-2 as an executioner protease. In contrast, the second pathway, caused by ATM deficiencyinduced meiotic defects, proceeds independently of caspase-2 and its upstream activator Bax.

\section{Results}

\section{Caspase-11 gene inactivation defines a novel pathway underlying female gametogenic failure}

In our ongoing efforts to elucidate the molecular genetics of programmed germ cell death in females, ${ }^{1}$ we discovered that caspase-11 null female mice were born with a severely compromised endowment of oocytes (Table 1). While most members of the caspase family are implicated in executing the programmed cell death pathway of apoptosis, ${ }^{23-26}$ caspase-11 is believed to function principally as a mediator of inflammation and related immune responses due to its obligate role in cleavage activation of procaspase-1 or interleukin (IL)-1 $\beta$-converting enzyme. ${ }^{27}$ Caspase- 1 is then required for generating a number of factors, including IL-1 $\beta$, $\mathrm{IL}-1 \alpha, \mathrm{IL}-18$ and $\gamma$-interferon, through proteolysis of cytokine proforms (IL-1 $\beta, \mathrm{IL}-18$ ), activating cofactors (IFN- $\gamma$ ) or as yet poorly understood mechanisms $(\mathrm{IL}-1 \alpha, \mathrm{IFN}-\gamma) \cdot{ }^{28-31}$ Indeed,
Table 1 Gametogenic failure in female mice lacking caspase-11 or IL-1 $\alpha / \beta$

\begin{tabular}{lcc}
\hline Genotype & $\begin{array}{c}\text { Primordial follicle } \\
\text { endowment/ovary }\end{array}$ & $\begin{array}{c}P \text {-value versus } \\
\text { respective wild-type }\end{array}$ \\
\hline Wild-type & $19.083 \pm 2.239$ & \\
Caspase-11 & $7.020 \pm 1.043$ & $P<0.01$ \\
Wild-type & $19.870 \pm 1.956$ & \\
$I L-1 \alpha^{-1-}$ & $21.253 \pm 1.102$ & $\mathrm{NS}$ \\
$I L-1 \beta^{-/-}$ & $21.690 \pm 1.151$ & $\mathrm{NS}$ \\
$I L-1 \alpha / \beta^{-/-}$ & $12.733 \pm 1.171$ & $P<0.05$ \\
\hline
\end{tabular}

Values are the total number of non-atretic (non-apoptotic) oocyte-containing primordial follicles per ovary (mean \pm S.E.M. of combined data from three independent experiments using different mice of each genotype in each experiment) at day 4 postpartum (NS, not significant)

the absence or severely impaired production of proinflammatory cytokines is phenocopied in caspase-11 and caspase-1 mutant mice. $27-29$

To test if defective lymphokine production in caspase11 deficient mice was at least partly responsible for excessive germ cell death in vivo, we first isolated and cultured wild-type fetal ovaries ex vivo without serum in the absence or presence of IL- $1 \alpha$ or IL-1 $\beta$ to assess the occurrence of germ cell apoptosis. While the effects of IL$1 \beta$ were more prominent, each cytokine alone suppressed apoptosis of fetal ovarian germ cells induced by survival factor deprivation during serum-free in vitro culture (Figure 1a). Furthermore, bromodeoxyuridine incorporation studies $^{9}$ revealed that $\mathrm{IL}-1 \alpha$ and $\mathrm{IL}-1 \beta$ promoted little, if any, fetal ovarian germ cell proliferation (data not shown), collectively indicating that the effects of $\mathrm{IL}-1 \alpha$ and $\mathrm{IL}-1 \beta$ were solely at the level of cell survival signaling. Importantly, immunohistochemical studies localizing the type $1 \mathrm{IL}-1$ receptor in germ cells of wild-type fetal ovaries (Figure 1b) confirmed that the germ cells per se were direct targets for IL-1 action. To provide further proof of an essential role for cytokines derived from caspase-11 function in repressing programmed death of female germ cells in vivo, we next examined mutant female mice lacking IL- $1 \alpha$, IL- $1 \beta$, or both $\mathrm{IL}-1 \alpha$ and $\mathrm{IL}-1 \beta$ (double mutants) for possible deficits in oocyte endowment. Mice deficient in either IL- $1 \alpha$ or IL- $1 \beta$ alone were born with a normal complement of germ cells (Table 1). However, neonatal female mice lacking both $\mathrm{IL}-1 \alpha$ and $\mathrm{IL}-1 \beta$ exhibited a significant reduction in oocyte numbers (Table 1).

\section{Caspase-2 gene inactivation rescues germ cells from death induced by caspase-11 deficiency}

Other members of the caspase family, such as caspase-2, caspase-3, caspase- 6 and caspase-7, have been implicated as downstream executioners of apoptosis in many somatic cell types. ${ }^{23-26}$ Interestingly, while caspase- 2 is dispensable for cell death to proceed normally in almost all tissues, caspase-2 deficient female mice exhibit a dramatic defect in developmental and anticancer drug-induced oocyte apoptosis. $^{32}$ To determine if gametogenic failure in caspase- 11 null females was dependent upon caspase-2 as an executioner 
molecule, we intercrossed caspase-11 mutants with caspase2 deficient mice to generate double mutant animals lacking both enzymes. Assessments of oocyte endowment shortly after birth revealed that germ cell numbers in caspase-11 deficient females were restored to normal (i.e., not different than wild-type) by caspase-2 gene disruption (Figure 2a). To support and extend these findings, we next used cultured fetal ovaries to model acute cytokine deprivation-induced apoptosis in the female germ line. ${ }^{9}$ Similar to that observed in vivo, germ cell death resulting from cytokine starvation in wild-type fetal ovaries was significantly attenuated in fetal ovaries collected from caspase-2 deficient females and cultured in parallel without cytokine support (Figure $2 b$ ).

\section{Caspase-2 gene inactivation fails to rescue germ cells from death induced by ATM deficiency}

As discussed earlier, Atm null germ cells die via apoptosis at or shortly after prophase I of meiosis. ${ }^{15}$ In the female, these events occur during fetal development and, thus, ATM deficient female mice are born with ovaries devoid of oocytes. To determine if this paradigm of prenatal germ cell
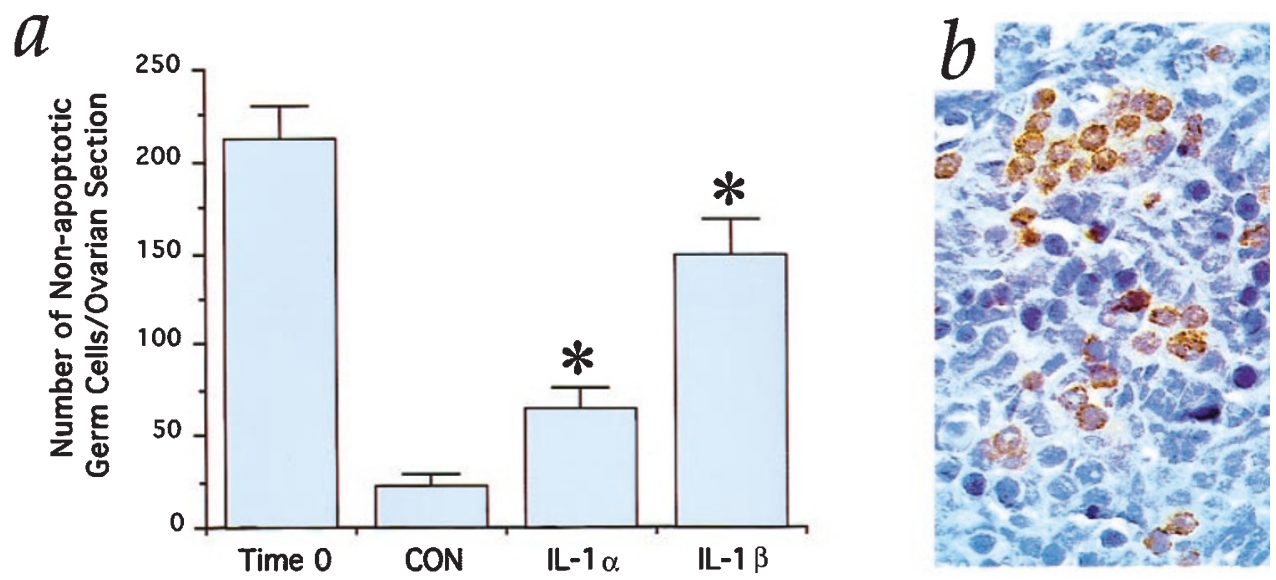

Figure 1 Interleukin- $1 \alpha$ and IL-1 $\beta$ directly repress fetal ovarian germ cell apoptosis. (a) Suppression of cytokine deprivation-induced apoptosis of germ cells in wild-type fetal ovaries ex vivo by treatment with $10 \mathrm{ng} / \mathrm{ml}$ of either IL- $1 \alpha$ or IL-1 $\beta$. Time 0 , no culture; CON, control culture without cytokine (mean \pm S.E.M. of combined data from three independent experiments with $2-3$ ovaries analyzed per treatment group in each experiment; ${ }^{\star} P<0.05$ versus control). (b) Representative immunohistochemical localization (brown staining) of type-1 IL-1 receptor expression in germ cells of e13.5 fetal ovaries. Original magnification: $\times 600$

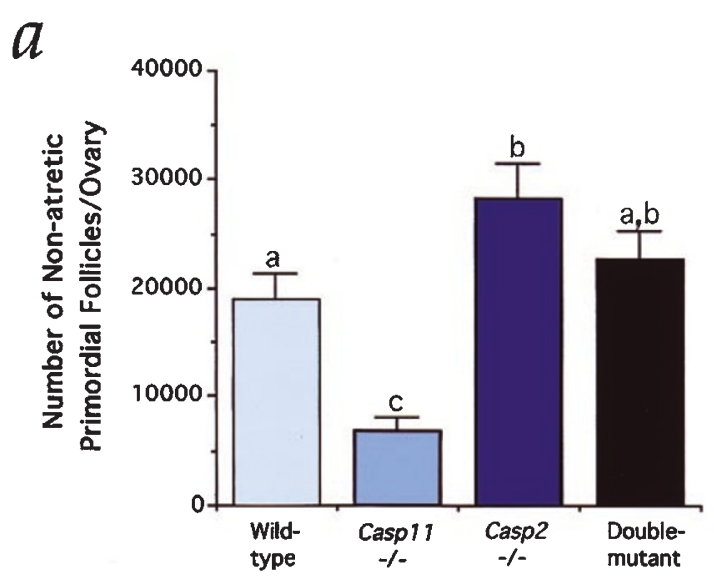

$b$

gure 2 Female gametogenic failure induced by cytokine deprivation in vivo or ex vivo is rescued by caspase-2 gene inactivation. (a) Non-apoptotic, oocytecontaining primordial follicle reserve at day 4 postpartum in ovaries of wild-type female mice or mutant (-/-) female mice lacking caspase-11, caspase-2, or both caspase-11 and caspase-2 (double mutant). The graph depicts the mean + S.E.M. of combined data from three independent experiments using different mice of each genotype in each experiment. Different letters indicate significant differences $(P<0.05)$. (b) Number of viable (non-apoptotic) germ cells present in fetal ovaries collected from wild-type $(+/+)$ or caspase-2 null $(-/-)$ female mice and cultured in parallel without cytokine support (mean \pm S.E.M. of combined data from three replicate experiments with $2-3$ ovaries analyzed per time point in each experiment; ${ }^{\star} P<0.05$ versus respective wild-type value) 
loss is also dependent upon caspase-2 as an executioner, we intercrossed Atm mutant mice with caspase-2 null mice to generate double mutant animals for analysis of oocyte endowment at birth. In striking contrast to the restoration of normal oocyte numbers in caspase-11 mutants (Figure 2a), caspase-2 gene inactivation was unable to rescue oocyte loss resulting from meiotic defects due to the absence of functional ATM (Figure $3 a-f)$.

\section{Bax gene inactivation fails to rescue germ cells from death induced by ATM deficiency}

Recent studies have demonstrated that Bax, a pro-apoptotic $\mathrm{Bcl}-2$ family member that functions upstream of caspase activation, ${ }^{33}$ cooperates with ATM in ionizing radiationinduced apoptosis in the central nervous system. ${ }^{34}$ Previous reports have also shown that Bax is required for developmental and anticancer therapy-induced oocyte death, ${ }^{35,36}$ that Bax directly induces apoptosis in isolated oocytes, ${ }^{37}$ and that Bax expression is increased in the testes of Atm mutant male mice as a potential mediator of germ cell depletion. ${ }^{38}$ Therefore, in a final set of studies we generated $\mathrm{Atm} / \mathrm{bax}$ double mutant mice to determine if deletion of this more upstream initiator of programmed cell death could spare ATM deficient oocytes from apoptosis. However, like caspase-2 gene inactivation, Bax deficiency also failed to rescue germ cells from death in Atm null females (Figure $3 a-d, g, h$ ).

\section{Discussion}

Although many growth factors and cytokines have been implicated in the control of germ cell fate during development, only two have been shown by gene mutation analysis to be important in vivo. ${ }^{6}$ The first involves SCF-dependent activation of its tyrosine kinase-coupled receptor, c-kit, since a null mutation in either gene (Steel or $W$ locus, respectively) leads to germ cell loss and sterility. ${ }^{6-8}$ The second is less well-defined but involves ligands, such as IL-6, IL-11, LIF, ciliary neurotrophic factor and/or oncostatin $M$, capable of activating the cytokine receptor-coupled gp130 signal transduction subunit, ${ }^{39}$ since mice lacking gp130 apparently have reduced germ cell numbers (discussed in reference ${ }^{40}$ ). Herein we have demonstrated by targeted gene disruption that IL- $1 \alpha$ and IL-1 $\beta$, proinflammatory cytokines derived from caspase-11/caspase-1 function, are novel germ cell survival factors functionally required in vivo for the endowment of a normal complement of oocytes at birth. The effects of these cytokines on the developing germ line appear to be direct since fetal ovarian germ cells express the type 1 receptor (which binds, and is activated by, both IL- $1 \alpha$ and IL- $1 \beta$ ), and either cytokine alone is capable of suppressing germ cell apoptosis in fetal ovaries otherwise starved of any cytokine support ex vivo.

This new function for IL- $1 \alpha$ and IL- $1 \beta$ stemmed from our unexpected findings of gametogenic failure in caspase-11 mutants, which are known to be resistant to bacterial lipopolysaccharide-induced lethality due to their inability to process procaspase-1 needed for lymphokine production. ${ }^{27}$ As such, we would predict a similar phenotype of failed gametogenesis in caspase-1 mutant female mice. However, such studies are complicated by observations that caspase-1 deficient mice do not express the caspase-11 gene ( $\mathrm{J}$ Yuan, unpublished observations), findings consistent with the fact that caspase-11 gene expression is induced by the proinflammatory responses lost in caspase1 null animals. ${ }^{41}$ We did note, however, that the gametogenic failure caused by the absence of $\mathrm{IL}-1 \alpha / \beta$ was not as severe as that resulting from caspase-11 gene inactivation. Therefore, cytokines other than IL- $1 \alpha$ and IL- $1 \beta$ that are absent or reduced in caspase-11 deficient mice probably act in conjunction with, or independent of, the IL-1 system to repress activation of a key intracellular step(s) required for programmed germ cell death. Of note, a recent study has shown that under certain pathological conditions
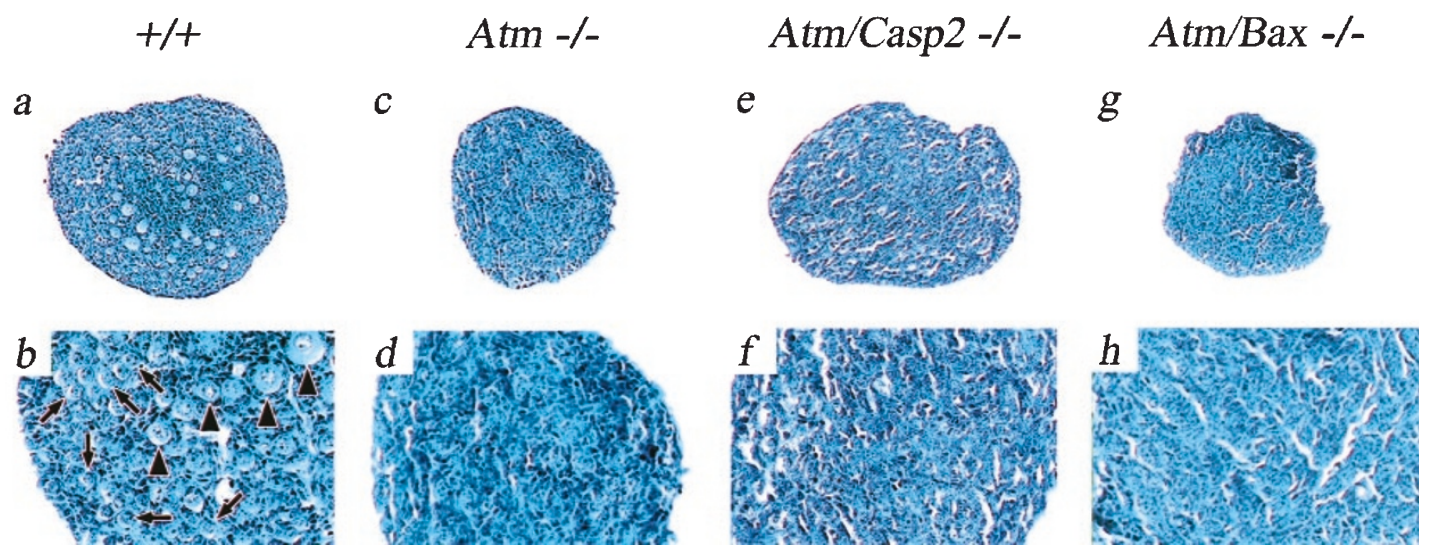

Figure 3 Disruption of either the caspase-2 or bax gene fails to rescue oocyte death induced by meiotic defects in Atm mutant mice. Representative (from three independent experiments using different mice for each genotype in each experiment) histological appearance of ovaries collected on day 4 postpartum from wildtype (+/+; a, b), Atm mutant (c, d), Atm/caspase-2 double mutant (e, f) or Atm/bax double mutant (g, h) female mice. Note the complete absence of oocytes in $\mathrm{Atm}^{-1-}$, Atm/caspase $-2^{-1-}$ and Atm/bax ${ }^{-1-}$ ovaries compared with representative oocyte-containing primordial and primary follicles designated by arrows and arrowheads, respectively, in the corresponding wild-type ovary (b). Original magnifications: a, c, e, g, $\times 100 ; \mathbf{b}, \mathbf{d}, \mathbf{f}, \mathbf{h}, \times 400$ 
of brain injury, caspase-11 can also function to process procaspase- 3 to the active enzyme. ${ }^{42}$ Such findings raise the possibility that failed caspase- 3 activation in caspase11 mutant mice is also at least partly responsible for the ovarian phenotype of germ cell deficiency. However, this is highly unlikely based on our recent observations that caspase-3 gene inactivation ${ }^{43}$ does not affect developmental nor anticancer therapy-induced apoptosis in female germ cells. ${ }^{43}$

Previous studies have shown that disruption of the gene encoding the downstream executioner molecule, caspase2 , leads to birth of female mice with an enlarged oocyte reserve. $^{32}$ This phenotype was attributed to a germ cellintrinsic death defect during prenatal ovarian development based on observations that caspase-2 null oocytes fail to undergo apoptosis following exposure to the anticancer drug, doxorubicin. ${ }^{32}$ Herein we have extended these findings by showing that germ cells within caspase-2 deficient fetal ovaries are indeed resistant to death caused by complete cytokine starvation in vitro, supporting the proposal that caspase-2 is central to the execution of developmental apoptosis in oocytes resulting from cytokine insufficiency. Moreover, the finding that the number of germ cells in fetal ovaries at embryonic day 13.5 was similar in wild-type and caspase-2 mutant mice prior to culture suggests that any germ line death prior to sexual differentiation of the embryonic gonads can occur independent of caspase-2. Nonetheless, the surfeit of oocytes present in caspase-2 deficient neonates ${ }^{32}$ prompted us to test if a loss of caspase-2 function in vivo could rescue the gametogenic failure caused by caspase11 gene inactivation.

Consistent with findings that germ cells in caspase-2 null fetal ovaries were resistant to cytokine deprivationinduced death ex vivo, normal oocyte endowment was restored in caspase-11 deficient females by the absence of functional caspase- 2 in vivo. Thus, one probable function of cytokines derived from the caspase-11/caspase-1 pathway in the developing female germ line is to suppress activation of the downstream executioner molecule caspase-2. Given these findings, we next explored the possibility that this effector caspase is also required for germ cell apoptosis induced by meiotic defects, another major stimulus for developmental oocyte death. However, analysis of ovaries collected from neonatal female mice lacking both ATM and caspase-2 revealed that, in striking contrast to the restoration of a normal oocyte reserve in caspase-11 mutant mice by caspase-2 gene inactivation, loss of caspase-2 function did not rescue oocytes from apoptosis in the Atm null background. It is conceivable that a cell death effector caspase other than caspase-2, such as caspase-3, caspase-6 or caspase-7, is responsible for ensuring the apoptotic deletion of Atm null oocytes. However, recent work in our laboratory using caspase-3deficient female mice has shown that this caspase family member is not required for female germ cell apoptosis. ${ }^{44}$ Unfortunately, caspase-7 gene inactivation is embryonic lethal, ${ }^{26}$ precluding the use of these animals for generation of double mutant mice. Although caspase- 6 deficient animals are an option for future study since homozygous null mice are viable, ${ }^{26}$ we elected to pursue this question by analysis of mutant mice lacking the pro-apoptotic Bcl-2 family member, Bax, ${ }^{45,46}$ an upstream activator of the caspase cascade. ${ }^{33}$

The Bax deficient mouse was a logical candidate for use in these experiments for several reasons. First, recent work has demonstrated that bax gene inactivation conveys in oocytes a striking resistance to both developmental $^{36}$ and anticancer therapy-induced ${ }^{35}$ apoptosis in vivo. Further, the bax gene is known to be expressed in murine oocytes, ${ }^{47,48}$ and increased expression of the endogenous bax gene has been suggested as a potential mediator of germ cell apoptosis in the testes of ATM deficient male mice. ${ }^{38}$ Finally, studies of Rucker and colleagues have shown that loss of Bax function in mice can rescue fetal oocytes from death resulting from hypomorphic expression of the $b c /-x$ gene. ${ }^{49}$ However, results from our experiments indicated that bax gene inactivation was unable to override programmed death of the entire oocyte population in Atm mutant females. Thus, the surveillance mechanisms responsible for deletion of meiotically-defective germ cells during development probably serve as integral quality control checkpoints during gametogenesis that are not amenable to modulation.

Such studies to elucidate the intracellular mechanisms by which programmed germ cell death is accomplished are important, not only for understanding the developmental processes underlying ovarian organogenesis, but also for delineating the basis of disease states characterized by gonadal dysgenesis. For example, excessive germ cell loss occurs in female mice possessing deletions in X-linked 'fertility' genes, such as Zfx ${ }^{50}$ Since a human $Z f x$ counterpart exists, ${ }^{51}$ some $X$-chromosome anomalies in humans may lead to oocyte loss and premature ovarian failure due to the functional absence of a key factor(s) needed for signaling germ cell survival. On the other hand, in female mice lacking the entire second $X$ chromosome $(\mathrm{XO}){ }^{52}$ it has been proposed that selective elimination of germ cells harboring meiotic defects is the basis of the resultant gonadal dysgenesis. Such mice exhibit a massive attrition of fetal oocytes, a phenotype recapitulated in female mice harboring a large $X$ chromosome inversion $(\operatorname{InX} / X){ }^{52}$ A similar situation of gonadal dysgenesis occurs in Ullrich-Turner syndrome (XO karyotype) $)^{53,54}$ and $\mathrm{Xq}$ duplication ${ }^{55}$ in humans. Consequently, elimination of meiotically defective germ cells carrying an unpaired or incompletely paired $\mathrm{X}$ chromosome is probably an evolutionarily conserved checkpoint to ensure the production of high-quality gametes. The inability of Bax or caspase-2 loss-offunction to rescue gametogenic failure in Atm mutant females is therefore intriguing since it suggests that therapeutic suppression of specifically Bax or caspase-2 would spare from apoptosis those oocytes without meiotic defects. The implications of this are significant in light of recent evidence that controlled regulation of oocyte apoptosis holds promise for managing the time to normal menopause and overcoming premature ovarian failure in women. ${ }^{1,35-37,56}$ 


\section{Materials and Methods}

\section{Mutant mouse lines}

Studies describing the generation of mice lacking caspase- $11,{ }^{27}$ caspase-2, ${ }^{32} \mathrm{IL}-1 \alpha,{ }^{57} \mathrm{IL}-1 \beta,{ }^{57} \mathrm{IL}-1 \alpha / \beta,{ }^{57} \mathrm{ATM}^{14}$ and $\mathrm{Bax}^{46}$ have been reported. Double mutant mice were generated by standard intercrossing protocols, and genotyping of mice was performed as originally detailed. All of the mutant mouse lines were backcrossed onto a congenic C576BL/6 background prior to experimentation. All animal work was conducted using protocols approved by institutional animal care and use committees of Massachusetts General Hospital, Harvard Medical School and University of Tokyo.

\section{Neonatal ovarian oocyte counts}

Ovaries were collected from the various lines of mice indicated at day 4 postpartum, a time in the mouse corresponding to the presence of peak numbers of oocyte-containing primordial ovarian follicles. ${ }^{1}$ One ovary of the pair from each animal was fixed $(0.34 \mathrm{~N}$ glacial acetic acid, $10 \%$ formalin, $28 \%$ ethanol), embedded in paraffin, and seriallysectioned $(8 \mu \mathrm{m})$. The serial sections from each ovary were aligned in order on glass microscope slides, stained with hematoxylin/picric acidmethyl blue, and analyzed for the number of healthy (non-atretic) oocyte-containing primordial follicles, as described. ${ }^{32,35-37,58}$ Several studies, including the present work (compare data shown in Figure $2 \mathrm{~B}$ and reference ${ }^{32}$ ), have shown that assessment of primordial oocyte numbers shortly after birth is a reliable predictor of changes in fetal ovarian germ cell death susceptibility. ${ }^{37,59}$

\section{Fetal ovarian cultures}

For studies of IL-1 ligand and receptor, fetuses were removed from timed-pregnant wild-type C57BL/6 female mice on embryonic day 13.5 (e13.5), a time just prior to the onset of in vivo fetal ovarian germ cell death. ${ }^{60}$ Fetal ovaries were collected and either fixed immediately or fixed after a $72 \mathrm{~h}$ culture in the absence or presence of $10 \mathrm{ng} / \mathrm{ml} \mathrm{IL-1 \alpha}$ or IL-1 $\beta$, as described previously. ${ }^{9}$ The total number of viable (nonapoptotic) germ cells/ovarian section was then determined by histomorphometric (cellular morphology, cell counts) and histochemical (in situ DNA 3'-end labeling) evaluations. ${ }^{9,61}$ Immunolocalization of the type $1 \mathrm{IL}-1$ receptor was performed using e13.5 ovaries fixed immediately after isolation in conjunction with an affinity-purified rabbit polyclonal antiserum raised against mouse type $1 \mathrm{IL}-1$ receptor (IL1R1 M-20, Santa Cruz Biotechnology, Santa Cruz, CA, USA) following high-temperature antigen unmasking, essentially as described. ${ }^{61}$ No reaction product was observed if the primary antibody was replaced with normal rabbit serum (data not shown). For studies with caspase-2 deficient mice, female fetuses were removed on e13.5 from timedpregnant wild-type and caspase-2 null female mice derived from the same colony of caspase- $2^{+/-}$(heterozygous) breeding animals. Fetal ovaries were collected and cultured in parallel for increasing lengths of time in the absence of cytokine support, after which the tissues were fixed and assessed for the total number of viable germ cells per ovarian section (see above).

\section{Data presentation and analysis}

All experiments were independently replicated with different mice at least three times. Graphs depict the mean \pm S.E.M. of combined data from the replicate experiments. Quantitative data were analyzed by a one-way analysis of variance followed by Scheffe's F-test, with significance assigned at $P<0.05$. For IL-1 receptor immunolocaliza- tion and ovarian histology, representative photomicrographs from at least three replicate experiments are presented.

\section{Acknowledgements}

We are indebted to $\mathrm{P}$ Leder for providing $\mathrm{Atm}^{+/-}$mice for breeding and generation of some of the double mutant animals (Atm/caspase-2 and Atm/bax) described herein, Z Fuks for early discussions concerning gametogenic failure in Atm null mice, J Flaws for technical assistance, and I Schiff for critical review of the manuscript prior to its submission. This work was supported by research grants from the National Institutes of Health to JL Tilly (R01-AG12279, R01-ES08430) and J Yuan (R01AG12859), from the National Science Foundation to $\mathrm{J}$ Yuan (IBN9418785), and by Vincent Memorial Research Funds to JL Tilly. During a part of these studies, $Y$ Morita was on leave from the Department of $\mathrm{OB} / \mathrm{GYN}$ of the University of Tokyo Faculty of Medicine, with funding from the Japanese Society for the Promotion of Science.

\section{References}

1. Morita Y and Tilly JL (1999) Oocyte apoptosis: like sand through an hourglass. Dev. Biol. 213: 1-17

2. Forabosco A, Sforza C, De Pol A, Vizzotto L, Marzona L and Ferrario VF (1991) Morphometric study of the human neonatal ovary. Anat. Rec. 231: 201-208

3. Baker TG (1963) A quantitative and cytological study of germ cells in human ovaries. Proc. R. Soc. Lond. (B) 158: 417-433

4. Beaumont HM and Mandl AM (1961) A quantitative and cytological study of oogonia and oocytes in the foetal and neonatal rat. Proc. R. Soc. Lond. (B) 155: $557-579$

5. Jacobson MD, Weil M and Raff MC (1997) Programmed cell death in animal development. Cell 88: $347-354$

6. Wylie C (1999) Germ cells. Cell 96: 165-174

7. Mintz B and Russell ES (1957) Gene-induced embryological modification of primordial germ cells in the mouse. J. Exp. Zool. 134: 207-230

8. Besmer P, Manova K, Duttlinger R, Huang EJ, Packer A, Gyssler C and Bachvarova R (1993) The kit-ligand (steel factor) and its receptor c-kit/W: pleiotropic roles in gametogenesis and melanogenesis. Development Supplement: $125-137$

9. Morita Y, Manganaro TF, TaoX-J, Martimbeau S, Donahoe PK and Tilly JL (1999) Requirement for phosphatidylinositol-3'-kinase in cytokine-mediated germ cell survival during fetal oogenesis in the mouse. Endocrinology 140: 941-949

10. Speed RM (1988) The possible role of meiotic pairing anomalies in the atresia of human fetal oocytes. Hum. Genet. 78: 260-266

11. Mittwoch U and Mahadevaiah SK (1992) Unpaired chromosomes at meiosis: cause or effect of gametogenic insufficiency? Cytogenet. Cell Genet. 59: 274279

12. Barlow C, Hirotsune S, Paylor R, Liyanage M, Eckhaus M, Collins F, Shiloh $Y$, Crawley JN, Ried T, Tagle D and Wynshaw-Boris A (1996) Atm-deficient mice: a paradigm of ataxia telangiectasia. Cell 86: 159-171

13. Xu Y, Ashley T, Brainerd EE, Bronson RT, Meyn MS and Baltimore D (1996) Targeted disruption of ATM leads to growth retardation, chromosomal fragmentation during meiosis, immune defects, and thymic lymphoma. Genes Dev. 10: 2411-2422

14. Elson A, Wang $Y$, Daugherty $C J$, Morton CC, Zhou F, Campos-Torres $J$ and Leder P (1996) Pleiotropic defects in ataxia-telangiectasia protein-deficient mice. Proc. Natl. Acad. Sci. USA 93: 13084-13089

15. Barlow C, Liyanage M, Moens PB, Tarsounas M, Nagashima K, Brown $\mathrm{K}$, Rottinghaus S, Jackson SP, Tagle D, Ried T and Wynshaw-Boris A (1998) Atm deficiency results in severe meiotic disruption as early as leptonema of prophase I. Development 125: 4007-4017

16. Canman CE and Lim DS (1998) The role of ATM in DNA damage responses and cancer. Oncogene. 17: 3301-3308

17. Rotman $G$ and Shiloh $Y$ (1999) ATM: a mediator of multiple responses to genotoxic stress. Oncogene. 18: 6135-6144 
18. Plug AW, Peters AH, XuY, Keegen KS, Hoekstra MF, Baltimore D, de Boer P and Ashley T (1997) ATM and RPA in meiotic chromosome synapsis and recombination. Nature Genet. 17: 457-461

19. Flaggs G, Plug AW, Dunks KM, Mundt KE, Ford JC, Quiggle MR, Taylor EM, Westphal CH, Ashley T, Hoekstra MF and Carr AM (1997) Atm-dependent interactions of a mammalian $\mathrm{CHK} 1$ homolog with meiotic chromosomes. Curr. Biol. 7: 977-986

20. Moens PB, Tarsounas M, Morita T, Habu T, Rottinghaus ST, Freire R, Jackson SP, Barlow C and Wynshaw-Boris A (1999) The association of ATR protein with mouse meiotic chromosome cores. Chromosoma 108: 95-102

21. Keegan KS, Holtzman DA, Plug AW, Christenson ER, Brainerd EE, Flaggs G, Bentley NJ, TaylorEM, Meyns MS, Moss SB, Carr AM, Ashley Tand Hoekstra MF (1996) The Atr and Atm protein kinases associate with different sites along meiotically pairing chromosomes. Genes Dev. 10: 2423-2437

22. Pandita TK, Westphal CH, Anger M, Sawant SG, Geard CR, Pandita RK and Scherthan H (1999) Atm inactivation results in aberrant telomere clustering during meiotic prophase. Mol. Cell Biol. 19: 5096-5105

23. Cryns V and Yuan J (1998) Proteases to die for. Genes Dev. 12: 1551-1570

24. Thornberry NA and Lazebnik Y (1998) Caspases: enemies within. Science 281 $1312-1316$

25. Nicholson DW (1999) Caspase structure, proteolytic substrates, and function during apoptotic cell death. Cell Death Differ. 6: 1028-1042

26. Zheng T, Hunot S, Kuida Kand Flavell RA (1999) Caspase knockouts: matters of life and death. Cell Death Differ. 6: 1043-1053

27. Wang S, Miura M, Jung YK, Zhu H, Li E and Yuan J (1998) Murine caspase-11, an ICE-interacting protease, is essential for the activation of ICE. Cell 92: 501-509

28. Kuida K, Lippke JA, Ku G, Harding MW, Livingston DJ, Su MS-S and Flavell RA (1995) Altered cytokine export and apoptosis in mice deficient in interleukin-1 $\beta$ converting enzyme. Science 267: 2000-2003

29. LiP, Allen H, Banerjee S, Franklin S, Herzog L, Johnston C, McDowell J, Paskind M, Rodman L, Salfeld J, Towne E, Tracey D, Wardwell S, Wei F-Y, Wong W, Kamen $\mathrm{R}$ and Seshadri T (1995) Mice deficient in IL-1 $\beta$-converting enzyme are defective in production of mature IL-1 $\beta$ and resistant to endotoxic shock. Cell 80 : 401-411

30. Gu Y, Kuida K, Tsutsui H, Ku G, Hsiao K, Fleming MA, Hayashi N, Higashino K, Okamura H, Nakanishi K, Kurimoto M, Tanimoto T, Flavell RA, Sato V, Harding MW, Livingston DJ and Su MS-S (1997) Activation of interferon- $\gamma$ inducing factor mediated by interleukin- $1 \beta$ converting enzyme. Science 275: 206-209

31. Dinarello CA (1999) Interleukin-18. Methods 19: 121-132

32. Bergeron L, Perez GI, Mcdonald G, Shi L, Sun Y, Jurisicova A, Varmuza S, Latham KE, Flaws JA, Salter J, Hara H, Moskowitz MA, Li E, Greenberg AH, Tilly $\mathrm{JL}$ and Yuan J (1998) Defects in regulation of apoptosis in caspase-2-deficient mice. Genes Dev. 12: 1304-1314

33. Korsmeyer SJ (1999) BCL-2 gene family and the regulation of programmed cel death. Cancer Res. 59: 1693S-1700S

34. Chong MJ, Murray MR, Gosink EC, Russell HR, Srinivasan A, Kapsetaki M, Korsmeyer SJ and McKinnon PJ (2000) Atm and Bax cooperate in ionizing radiation-induced apoptosis in the central nervous system. Proc. Natl. Acad. Sci. USA 97: 889-894

35. Perez GI, Knudson CM, Leykin L, Korsmeyer SJ and Tilly JL (1997) Apoptosisassociated signaling pathways are required for chemotherapy-mediated female germ cell destruction. Nature Med. 3: 1228-1232

36. Perez Gl, Robles R, Knudson CM, Flaws JA, Korsmeyer SJ and Tilly JL (1999) Prolongation of ovarian lifespan into advanced chronological age by Baxdeficiency. Nature Genet. 21: 200-203

37. Morita Y, Perez Gl, Paris F, Miranda S, Ehleiter D, Haimovitz-Friedman A, Fuks Z, Xie Z, Reed JC, Schuchman EH, Kolesnick RN and Tilly JL (2000) Oocyte apoptosis is suppressed by disruption of the acid sphingomyelinase gene or by sphingosine-1-phosphate therapy. Nature Med. 6: 1109-1114

38. Barlow C, Liyanage M, Moens PB, Deng CX, Ried T and Wynshaw-Boris A (1997) Partial rescue of the prophase I defects of Atm-deficient mice by $p 53$ and $p 21$ nul alleles. Nature Genet. 17: 462-466

39. Kishimoto T, Tanaka T, Yoshida K, Akira S and Taga T (1995) Cytokine signa transduction through a homo- or heterodimer of gp130. Ann. NY. Acad. Sci. 766: 224-234

40. Hara T, Tamura K, de Miguel MP, Mukouyama Y, Kim HJ, Kogo H, Donovan PJ and Miyajima A (1998) Distinct roles of oncostatin M and leukemia inhibitory factor in the development of primordial germ cells and Sertoli cells in mice. Dev. Biol. 201: 144-153
41. Wang S, Miura M, Jung YK, Zhu H, Gagliardini V, Shi L, Greenberg AH and Yuan J (1996) Identification and characterization of caspase-11, a member of the ICE/ CED-3 family and an upstream regulator of ICE. J. Biol. Chem. 271: 2058020587

42. Kang S-J, Wang S, Hara H, Peterson EP, Namura S, Amin-Hanjani S, Huang Z, Srinivasan A, Thomaselli KJ, Thornberry NA, Moskowitz MA and Yuan J (2000) Dual role of caspase-11 in mediating activation of caspase-1 and caspase-3 under pathological conditions. J. Cell. Biol. 149: 613-622

43. Kuida K, Zheng TS, NaS, Kuan C, Yang D, Karasuyama H, Rikic P and Flavell RA (1996) Decreased apoptosis in the brain and premature lethality in CPP32deficient mice. Nature 384: $368-372$

44. Matikainen T, Perez GI, Zheng TS, Kluzak TR, Rueda BR, Flavell RA and Tilly JL (2001) Caspase-3gene knockout defines cell lineage specificity for programmed cell death signaling in the ovary. Endocrinology 142: in press

45. Oltvai ZN, Milliman CL and Korsmeyer SJ (1993) Bcl-2 heterodimerizes in vivo with a conserved homolog, Bax, that accelerates programmed cell death. Cell 74: $609-619$

46. Knudson CM, Tung KS, Tourtellotte WG, Brown GA and Korsmeyer SJ (1995) Bax-deficient mice with lymphoid hyperplasia and male germ cell death. Science 270: $96-99$

47. Jurisicova A, Latham KE, Casper RF and Varmuza SL (1998) Expression and regulation of genes associated with cell death during murine preimplantation embryo development. Mol. Reprod. Dev. 51: 243-253

48. De Felici M, Carlo AD, Pesce M, Iona S, Farrace MG and Piacentini M (1999) Bcl2 and Bax regulation of apoptosis in germ cells during prenatal oogenesis in the mouse embryo. Cell. Death Differ. 6: 908-915

49. Rucker EB, Dierisseau $P$, Wagner KU, Garrett L, Wynshaw-Boris A, Flaws JA and Hennighausen L (2000) Bcl-x and Bax regulate mouse primordial germ cell survival and apoptosis during embryogenesis. Mol. Endocrinol. 14: 1038-1052

50. Luoh SW, Bain PA, Polakiewicz RD, Goodheart ML, Gardner H, Jaenisch R and Page DC (1997) Zfx mutation results in small animal size and reduced germ cell number in male and female mice. Development 124: 2275-2284

51. Page DC, Disteche CM, Simpson EM, de la Chapelle A, Andersson M, Alitalo T, Brown LG, Green P and Akots G (1990) Chromosomal localization of ZFX-a human gene that escapes $X$ inactivation - and its murine homologs. Genomics 7: $37-46$

52. Burgoyne PS and Baker TG (1985) Perinatal oocyte loss in XO mice and its implications for the aetiology of gonadal dysgenesis in XO women. J. Reprod. Fertil. 75: 633-645

53. Christin-Maitre S, Vasseur C, Portnoi MF and Bouchard P (1998) Genes and premature ovarian failure. Mol. Cell. Endocrinol. 145: 75-80

54. Zinn AR and Ross JL (1998) Turner syndrome and haploinsufficiency. Curr. Opin. Genet. Dev. 8: 322-327

55. Correa-Cerro L, Garcia-Cruz D, Ruiz MX and Sanchez-Corona J (1999) Denovo duplication of Xq22-q23 in a girl with short stature and gonadal dysgenesis. Ann. Genet. 42: 41-44

56. Reynolds $T$ (1999) Cell death genes may hold clues to preserving fertility after chemotherapy. J. Natl. Cancer Inst. 91: 664-666

57. Horai R, Asano M, Sudo K, Kanuka H, Suzuki M, Nishihara M, Takahashi M and Iwakura Y (1998) Production of mice deficient in genes for interleukin (IL)-1 $\alpha$, IL$1 \beta$, IL-1 $\alpha / \beta$, and IL-1 receptor antagonist shows that IL-1 $\beta$ is crucial in turpentineinduced fever development and glucocorticoid secretion. J. Exp. Med. 187: $1463-1475$

58. Morita Y, Perez GI, Maravei DV, Tilly KI and Tilly JL (1999) Targeted expression of $\mathrm{Bcl}-2$ in mouse oocytes inhibits ovarian follicle atresia and prevents spontaneous and chemotherapy-induced oocyte apoptosis in vitro. Mol. Endocrinol. 13: 841-850

59. Robles R, Morita Y, Mann KK, Perez GI, Yang S, Matikainen T, Sherr DH and Tilly $\mathrm{JL}(2000)$ The aryl hydrocarbon receptor, a basic helix-loop-helix transcription factor of the PAS gene family, is required for normal ovarian germ cell dynamics in the mouse. Endocrinology 141: 450-453

60. Ratts VS, Flaws JA, Kolp R, Sorenson CM and Tilly JL (1995) Ablation of bcl-2 gene expression decreases the numbers of oocytes and primordial follicles established in the post-natal female mouse gonad. Endocrinology 136: 36653668

61. Morita Y and Tilly JL (1999) Segregation of the actions of retinoic acid on fetal ovarian germ cell mitosis versus apoptosis by requirement for new macromolecular synthesis. Endocrinology 140: 2696-2703 